\title{
Zaniedbane paradygmaty formacyjne nastolatka
}

The Neglected Formative Paradigms

of a Teenager

\begin{abstract}
ABSTRAKT
Najbardziej zagrożonq grupq społecznq, narażonq na negatywne skutki zmian cywilizacyjnych, jest młodzież będqqa podatnym gruntem dla manipulacji oraz sugestywnego kreowania mody i trendów. W tym kontekście autor podejmuje refleksję nad procesem wychowania i formacji młodego pokolenia. Czyni to, odwołujac się do pewnych paradygmatów formacyinych, które wydaja się w obecnym czasie zaniedbane, zapomniane lub marginalizowane ze względu na to, że sq niewygodne. Autor najpierw uściśla takie pojęcia, jak paradygmat i formacja. Następnie omawia dziewięć zaniedbanych paradygmatów formacyinych nastolatka. Sq nimi: paradygmat teleologiczny, ograniczonego zaufania, kontrolowanej samodzielności, indywidualnego podejścia, detoksykacyiny, wychowania przez obecność, destereotypizacyiny, ekologiczny oraz paradygmat spirytualny.
\end{abstract}

\section{ABSTRACT}

The most endangered social group who are vulnerable to the adverse effects of civilizational changes are youth, a fertile ground for manipulation and the suggestive creation of fashion and trends.
SLOWA KLUCZOWE

zaniedbanie, paradygmat, formacja, nastolatek, marginalizacja

KEYWORDS

neglect, paradigm, formation, teenager, marginalization
SPI Vol. 20, 2017/2

ISSN 2450-5358

e-ISSN 2450-5366

DOI: 10.12775/SPI.2017.2.004

Artykuły i rozprawy 
In this context, the author reflects on the process of education and formation of the young generation. He does this by referring to certain paradigms of formation, which seem at the present time neglected, forgotten or marginalized because they are uncomfortable. The author first, however, clarifies concepts such as paradigm and formation. Then the nine neglected formative paradigms of a teenager are discussed. These are: the teleological paradigm, the paradigm of limited trust, the paradigm of controlled self-reliance, the paradigm of individual approach, the detoxification paradigm, the paradigm of upbringing by presence, the de-stereotyping paradigm, the ecological paradigm and the spiritual paradigm.

Współczesna cywilizacja jawi się jako przestrzeń ogromnych zmian i wyzwań, co niesie ze sobą niezwykle dynamiczną strukturę wzajemnych powiązań i zależności. Cywilizacja XXI wieku jest globalną wioską, w której obywatel świata ma zarówno wielkie możliwości rozwoju, jak i niezliczone okazje do dekonstrukcji swojej osobowości. Niejednokrotnie prowadzi to do niebezpiecznego indywidualizmu i kreowania egoizmu. Trudno nie zgodzić się z poglądem Zygmunta Baumana, który twierdzi, że

w zindywidualizowanym społeczeństwie nie ma korzystnych warunków do solidarnego działania; nie pozwala się dostrzec lasu za drzewami. Ponadto stare drzewa, widok kiedyś znany i łatwo rozpoznawalny, zdziesiątkowano, a nowych raczej się nie posadzi, skoro uprawę ziemi powierzono indywidualnym drobnym farmerom. Zindywidualizowane społeczeństwo znamionuje rozmycie więzi społecznych, tego fundamentu solidarnego działania. Znane jest ono także ze swojego oporu przed solidarnością, która mogłaby utrwalić i uwiarygodnić więzi społeczne ${ }^{1}$.

Nie ma też wątpliwości, że najbardziej zagrożoną grupą społeczną, narażoną na negatywne skutki zmian cywilizacyjnych, jest młodzież będąca podatnym gruntem dla manipulacji oraz sugestywnego kreowania mody i trendów. Środowisko nastolatków jest jak gąbka nasiąkająca nowościami i ideami proponującymi miraż szczęścia i samorealizacji.

W tym kontekście warto podjąć refleksję nad procesem wychowania i formacji młodego pokolenia. Można to uczynić odwołując się

1 Z. Bauman, Ptynny lęk, tłum. J. Margański, Kraków 2008, s. 40. 
do pewnych paradygmatów formacyjnych, które wydają się w obecnym czasie zaniedbane, zapomniane lub marginalizowane ze względu na to, że są niewygodne. Zanim jednak zostaną one omówione, należy uściślić pojęcia formacji i paradygmatu.

Paradygmat to „zespół norm, wzorców, reguł postępowania, które zna każdy naukowiec zajmujący się daną nauką" ${ }^{2}$. Zaś paradygmat edukacyjny to „zestaw przeświadczeń i założeń na temat istoty i celów szkolnictwa, nauczania, nauczycieli oraz edukacji, ujawniający się w różnych formach praktyki kształcenia nauczycieli”’3.

$Z$ kolei formacja to „wywieranie trwałych wpływów przez jedną osobę, grupę, instytucję na osobowość innego człowieka w celu ukształtowania $\mathrm{w}$ nim psychicznych struktur poznawczo-oceniających $\mathrm{z}$ internalizacją systemu przekonań i systemu wartości oraz wytworzenia $\mathrm{z}$ nich umiejętnych działań w określonym kierunku"4. Natomiast formacja chrześcijańska - jak ją określa Jan Paweł II w adhortacji apostolskiej o powołaniu i misji świeckich w Kościele i świecie Christifideles laici - oznacza „stały proces osobistego dojrzewania i upodabniana się do Chrystusa, zgodnie z wolą Ojca, pod kierunkiem Ducha Świętego"s.

Wydaje się, że mając uściślone pojęcia-klucze, można wyróżnić dziewięć zaniedbanych paradygmatów formacyjnych nastolatka. Są nimi: paradygmat teleologiczny, ograniczonego zaufania, kontrolowanej samodzielności, indywidualnego podejścia, detoksykacyjny, wychowania przez obecność, destereotypizacyjny, ekologiczny oraz paradygmat spirytualny.

\section{Paradygmat teleologiczny}

Powyższy paradygmat związany jest $\mathrm{z}$ ideą wspomagania integralnego rozwoju nastolatka. Owa idea jest często intuicyjną strukturą tkwiącą w umyśle rodziców i wychowawców. Nie ma wątpliwości,

2 I. Bobrowski, Zaproszenie do jezzykoznawstwa, Kraków 1998, s. 33.

3 K. Zeichner, Alternative Paradigms of Teacher Education, „Journal of Teacher Education" 1983, t. 34, nr 3, s. 3.

4 Z. Chlewiński, Formacja, w: Encyklopedia katolicka, t. 5, red. L. Bieńkowski $\mathrm{i}$ in., Lublin 1989, kol. 389.

5 Jan Paweł II, Adhortacja Apostolska „Christifideles laici”, Kraków 1988, nr 57. 
że ustalenie konkretnych celów wychowawczych czy formacyjnych stanowi priorytet dla skutecznego oddziaływania na młodego człowieka. W tym obszarze istotna jest postawa odpowiedzialności, która

wymaga spełnienia czterech warunków: wiem, co robię, znam cel działania, przewiduję konsekwencje, przyjmuję i ponoszę te konsekwencje. [...] Uczenie odpowiedzialności polega na kształtowaniu samodzielności, czyli wyrabianiu gotowości do podejmowania decyzji oraz umiejętności radzenia sobie $\mathrm{z}$ problemami. Ważny jest $\mathrm{w}$ tym procesie fakt, by wybór był skierowany ku wartościom, a nie stawał się ucieczką przed wysiłkiem i trudnościami ${ }^{6}$.

Niestety, przypadkowość i nieskuteczność metod formacyjnych biorą się z braku jasno sprecyzowanych celów. Ponadto cele wychowawcze, które niekiedy są tylko pięknym postulatem przelanym na papier, dowodzą inercji wychowawczej, a w konsekwencji prowadzą do marginalizacji instytucji powołanych do wychowywania. Paradygmat teleologiczny ustawia cele w powiązaniu z wartościami, co przyczynia się do skutecznej formacji i jest odpowiedzią na potrzeby rozwojowe nastolatka. Jakże w tym miejscu nie zacytować Jana Pawła II, który przed laty przypominał, że

nie wystarczy patrzeć tylko w wyimaginowaną przyszłość, ale trzeba ją już teraz jakoś tworzyć, trzeba mieć przed oczyma całą tradycję narodu, społeczeństwa, państwa. Powiedział ktoś słusznie, że narody, które tracą pamięć, schodzą do rzędu plemienia. [...] Młody człowiek jest wrażliwy na prawdę, sprawiedliwość, piękno, na inne wartości duchowe. Młody człowiek pragnie odnaleźć siebie samego, dlatego szuka, czasem burzliwie szuka, prawdziwych wartości i ceni tych ludzi, którzy ich nauczają i według nich żyją ${ }^{7}$.

\section{Paradygmat ograniczonego zaufania}

Problem zaufania w wychowaniu jest niezwykle złożoną kwestią. W dobie liberalnych trendów wychowawcy zapominają o tym, że wychowanek powinien być dyskretnie kontrolowany. Niestety, obecnie nadmierne zaufanie do wychowanka może wynikać albo z naiwności,

6 A. Skreczko, Wychowanie do odpowiedzialności, „W Służbie Miłosierdzia” 2007, nr 11, s. 4.

7 Jan Paweł II, Przemówienie do katechetów nauczycieli i uczniów (Wtoctawek, 6.06.1991), „L'Osservatore Romano”1991, nr 6, s. 6. 
albo $\mathrm{z}$ chęci bycia nowoczesnym rodzicem czy wychowawcą, lub też z faktu, że nie posiada się konkretnej, skutecznej taktyki wychowawczej. Zarówno brak zaufania do wychowanka, jak i nadmierne oraz bezkrytyczne ufanie w jego możliwości, lojalność i roztropność stanowią poważny błąd natury wychowawczej ${ }^{8}$.

Paradygmat ograniczonego zaufania jest rzeczywiście zaniedbany, bowiem nie jest w modzie ograniczanie wychowanka. W wielu współczesnych koncepcjach pedagogicznych podkreśla się autonomię i wolność człowieka. Przesadne akcentowanie tych wartości może prowadzić do obdarzania wychowanka zbytnim zaufaniem, co skutkuje niebezpieczeństwem jego uwikłania się w różnego rodzaju uzależnienia i ryzykowne zachowania.

Trzeba pamiętać, że „zaufanie opiera się na opinii jednostki na temat zachowania się innej osoby w jakiejś sytuacji w przyszłości”" Wychowawca, który obdarza zaufaniem wychowanka, przewiduje niejako przyszłość. Jest ona jednak w pewnym sensie kreowana przez samego wychowanka, który ma ograniczone pole widzenia wynikające $\mathrm{z}$ braku chociażby mniejszego niż wychowawca doświadczenia.

Mówiąc o paradygmacie ograniczonego zaufania, trzeba także wspomnieć o drugim podmiocie wychowania, jakim jest sam wychowawca. On także powinien mieć pewien dystans do swoich decyzji i metod wychowawczych. Ograniczone zaufanie do siebie generuje pokorę wychowawczą i likwiduje dogmatyzm edukacyjny. Nie chodzi tu oczywiście o niepewność wychowawcy czy kształtowanie w sobie postawy wątpliwości co do słuszności własnych decyzji. Jest to raczej postawa nacechowana refleksyjnością nad swoimi poczynaniami.

Ograniczone zaufanie w wychowaniu niesie ze sobą wiele pozytywnych skutków i daje poczucie bezpieczeństwa obu podmiotom wychowania. Trzeba też pamiętać, że

zaufanie nie jest ulotną właściwością, którą się posiada lub nie; zaufanie jest pragmatyczną, a jednocześnie narażoną na utratę wartością. W czasach, gdy skandale, intrygi, brak istotnych więzi interpersonalnych, wreszcie zagrożenie terroryzmem, obniżyły poziom zaufania w stosunkach prywatnych, oficjalnych, tym bardziej - w międzynarodowych, zdolność jego budowania jest ważną kwestią nie tylko indywidualnej i społecznej potrzeby; stanowi również warunek konieczny

8 J. Mastalski, Jak dobrze wychować dziecko, Kraków 2014, s. 102.

9 P. Sztompka, Zaufanie. Fundament spoteczeństwa, Kraków 2007, s. 69. 
(conditio sine qua non) skuteczności wychowania młodego pokolenia do życia $\mathrm{w}$ rodzinie $\mathrm{i} \mathrm{w}$ społeczeństwie $\mathrm{w}$ warunkach postępującego procesu globalizacji świata ${ }^{10}$.

Paradoksalnie, deficyt zaufania generuje chęć powiększenia tej przestrzeni w obszarze wychowania.

\section{Paradygmat kontrolowanej samodzielności}

Wychowawcy powinni uwierzyć w możliwości swoich wychowanków i stawiać na ich samodzielność. Wychowanie do odpowiedzialności za siebie, za swoje wybory, jest fundamentem kształtowania dojrzałej osobowości. Wszelkie ograniczenia w tej dziedzinie są toksyczne, zatem wyręczanie dziecka powinno następować wyłącznie w sytuacjach przerastających jego możliwości. Niestety, zbyt częste wyręczanie prowadzi do wytworzenia bezradności w sytuacjach wymagających samodzielności. Dzieci nadmiernie chronione nie nadążają za rozwojem ruchowym i społecznym rówieśników. Hamowanie ich samodzielności nie pozwala na nabywanie nowych doświadczeń i zakłóca kolejne etapy rozwojowe. Nadopiekuńczość wywołuje u dziecka poczucie zagrożenia, nasila lęk i skłania do nadmiernej koncentracji na własnej osobie ${ }^{11}$.

Obserwuje się w ostatnich latach tzw. zjawisko helicopter parent, czyli takich rodziców, których możemy określić mianem nadopiekuńczych. Ich zachowanie obejmuje nadmierne zaangażowanie w obszar wielu aktywności oraz sfer swojego dziecka. A przecież Jan Paweł II pisał w Liście do Rodzin, że

proces wychowawczy prowadzi do fazy, do której się dochodzi wtedy, gdy po osiągnięciu pewnego stopnia dojrzałości psychofizycznej człowiek zaczyna wy ch ow ywać się s a m. Z biegiem czasu owo samowychowanie przerośnie poniekąd dotychczasowy proces wychowawczy. Młody człowiek spotyka nowe osoby i nowe środowiska, a w szczególności nauczycieli i kolegów w szkole, którzy zaczynają odgrywać w jego życiu wpływ wychowawczy, dodajmy: dodatni albo ujemny ${ }^{12}$.

10 S. Szałach, Zaufanie w relacjach interpersonalnych - wybrane aspekty, „Edukacja Humanistyczna” 2013, nr 1(28), s. 177.

11 J. Mastalski, Jak dobrze wychować dziecko, dz. cyt., s. 95.

12 Jan Paweł II, List do Rodzin, Kraków 1998, nr 16. 
W tym kontekście paradygmat kontrolowanej samodzielności jawi się jako usamodzielnianie $\mathrm{z}$ dyskretnym podglądem prawidłowości wchodzenia wychowanka na drogę odpowiedzialności za siebie i swoje wybory. Nie ma wątpliwości, że dyskretne i stopniowe usamodzielnianie leży u podstaw stawania się dojrzałym, rozwijającym swoje zasoby człowiekiem. Kontrolowana samodzielność to nie wyręczanie wychowanka, lecz czuwanie nad prawidłowością procesu usamodzielniania. Trzeba bowiem pamiętać, że samodzielność związana jest „z gotowością do podjęcia kolejnych prób działania w celu realizacji zamierzenia, a także $\mathrm{z}$ umiejętnością poniesienia konsekwencji własnych wyborów i decyzji”"13. Pomoc wychowawców w tym zakresie w postaci dyskretnego podpowiadania czy retuszowania wydaje się nie do przecenienia.

\section{Paradygmat indywidualnego podejścia}

Ekonomizacja edukacji sprawiła, że coraz częściej w miejsce indywidualizacji procesu wychowania dochodzi do zahamowania wzrostu psychoduchowego wychowanka. Tego typu ekonomizacja prowadzi do odpodmiotowienia uczniów i samego nauczyciela. Dostrzega się przecież już redukcję ćwiczeń na wielu kierunkach studiów wyższych, a także zmniejszenie liczby godzin niektórych przedmiotów w gimnazjach czy szkołach ponadgimnazjalnych. Ponadto ekonomia wymusza łączenie grup i klas, co niewątpliwie wpływa na jakość kształcenia. Niestety, nadal można zaobserwować zjawisko zatrudniania tzw. „tańszych nauczycieli”. Ze względu na oszczędności dyrektorowi bardziej opłaca się zatrudnić nauczyciela kontraktowego niż dyplomowanego ${ }^{14}$.

Wydaje się słuszny pogląd reprezentowany przez wielu pedagogów i psychologów, a w latach 60. XX wieku lansowany przez Henryka Rowida, że na „plan pierwszy wszelkiej działalności wychowawczej wysuwa się zasada indywidualizacji polegająca na uwzględnianiu właściwości psychicznych każdego dziecka, tempa jego rozwoju cielesnego i duchowego, poziomu jego inteligencji, zainteresowań,

13 K. Kuszak, Dynamika rozwoju samodzielności dziecka w wieku przedszkolnym, Poznań 2006, s. 7.

14 J. Mastalski, Przestrzenie obaw i dylematów zwiqzanych z jakościa ksztatcenia, w: Jakość innowacji i erwaluacja w edukacji, red. J. Grzesiak, Kalisz 2015, s. 45. 
uzdolnień, charakteru itp."15. Kształtowanie osobowości wychowanka, opanowywanie przez niego wiedzy o świecie i sposobów działania w nim staje się tym skuteczniejsze, im w większym stopniu jest dostosowane do indywidualnych możliwości wychowanków, im bardziej tak w kształtowaniu, jak i w przekształcaniu uwzględnia się jednostkowe struktury jego osobowości ${ }^{16}$.

Indywidualizacja $\mathrm{w}$ wychowaniu stanowi priorytetowe zadanie dla wychowawców, którzy chcą w sposób skuteczny wspierać rozwój wychowanka. Jak twierdzą specjaliści,

tylko poprzez uwzględnianie w procesie dydaktyczno-wychowawczym różnic indywidualnych między uczniami i stosowaniu takich zabiegów pedagogicznych, które (przy uwzględnieniu owych różnic) sprzyjają optymalnemu rozwojowi osobowości uczących się, stwarzamy szanse urzeczywistnienia potrzeb i możliwości uczniów. Indywidualizacja jako norma postępowania pedagogicznego stanowi warunek powodzenia realizacji procesu dydaktyczno-wychowawczego ${ }^{17}$.

\section{Paradygmat detoksykacyiny}

W ogromnym galimatiasie w obszarze zagrożeń, wartości i wyzwań cywilizacyjnych działania detoksykacyjne w wychowaniu mają szczególne znaczenie. Istnieje ogromna potrzeba detoksykacji stylu życia poprzez docenienie chociażby duchowych narzędzi prozdrowotnych, takich jak np. cisza sprzyjająca autorefleksji. Paradygmat detoksykacyjny kieruje człowieka do działań na rzecz przeciwdziałania tym skutkom cywilizacyjnego rozwoju, w których nie ma miejsca na integralny rozwój. Brak działań detoksykacyjnych sprawia, że następuje powolny proces depersonalizacji. Polega ona na oddalaniu się, dystansowaniu od drugiego człowieka, braku podejścia indywidualnego do spotykanych osób. Związana jest z powierzchownym uczestnictwem w procesie edukacyjnym. Działania detoksykacyjne w obszarze edukacyjnym powinny zmierzać w kierunku integralnego rozwoju zarówno nauczyciela, jak i ucznia.

15 H. Rowid, Podstawy i zasady wychowania, Warszawa 1957, s. 225.

16 J. Mastalski, Zasady edukacyjne w katechezie, Kraków 2002, s. 55.

17 A. Hłobił, Indywidualizacja ksztatcenia szansq urzeczywistnienia potrzeb i możliwości uczniów, „Edukacja Humanistyczna” 2015, nr 1(32), s. 113. 
Tempo życia i lansowane globalne postawy sprawiają, że paradygmat detoksykacyjny w wychowaniu może być zagubiony, zmarginalizowany. Już Erich Fromm przed laty ostrzegał, że

nowoczesny człowiek wyobcowuje się od siebie, od swoich bliźnich, od natury. Został przekształcony w towar, traktuje swoje siły żywotne jako inwestycję, która musi mu przynieść maksymalny zysk możliwy do osiągnięcia przy istniejących warunkach rynkowych. Stosunki, jakie łączą ludzi, są w zasadzie stosunkami wyobcowanych automatów, przy czym każdy opiera swoje bezpieczeństwo na trzymaniu się blisko stada i na niewyróżnianiu się od innych w myśli, uczuciach czy działaniu. Chociaż każdy usiłuje trzymać się możliwie jak najbliżej innych, pozostaje jednak zupełnie samotny, przepełniony głębokim uczuciem niepewności, niepokoju i winy, co występuje zawsze, gdy człowiekowi nie udaje się przezwyciężyć osamotnienia ${ }^{18}$.

Działania detoksykacyjne mają powyższym procesom przeszkodzić. Wychowawca jako detoksykator ma za zadanie uwrażliwiać wychowanka na zagrożenia, przestrzegać go przed ewentualnymi skutkami zachowań ryzykownych, jak i zachęcać do działań profilaktycznych w tym zakresie. Trzeba bowiem pamiętać, że

współczesny człowiek żyje w świecie, który jest rzeczywistością stechnicyzowaną, zaplanowaną, wyznaczoną. Mimo zdobyczy nauki i techniki, które odciążają ludzi od żmudnej pracy, coraz bardziej odczuwamy brak czasu. [...] Zorientowana postmodernistycznie kultura współczesna skupia ludzką uwagę bez reszty na teraźniejszości, która jawi się jako szczyt rozwoju. Teraźniejszość ma gwarantować człowiekowi wolność w konsumpcji, realizacji hedonistycznych upodobań i zabawie ${ }^{19}$.

\section{Paradygmat wychowania przez obecność}

Nie ma wątpliwości, że

w szeroko rozumianym przekazie wychowawczym w zakresie ról małżeńsko-rodzinnych uwidacznia się z jednej strony siła tradycji chrześcijańskiej, z drugiej - liberalizm, wartości religijne i świeckie, materialne i niematerialne. Ludzie młodzi mają dziś nieznaną nigdy wcześniej możliwość wyboru określonego wariantu w praktyce życia osobistego. Oczywiście,

18 E. Fromm, O sztuce mitości, tłum. A. Bogdański, Warszawa 1994, s. 76.

19 K. Denek, Wstronępedagogiki czasu, w: Opieka. Wychowanie. Ksztatcenie. Moduty edukacyjne, red. W. Woronowicz, D. Apanel, Kraków 2010, s. 16. 
wpływów agend socjalizacji nie należy traktować skrajnie deterministycznie, ale nie należy ich pomniejszać. Wiedza, w jaką wyposaża dziś jednostkę rodzina, szkoła, Kościól, może być przez nią rozwijana, pogłębiana lub odrzucana, zaprzeczana, a nawet potraktowana obojętnie ${ }^{20}$.

Stąd też tak ważna jest obecność wychowawców (w tym szczególnie rodziców) w codziennym życiu wychowanka.

Nie chodzi tu tylko obecność fizyczną. Ma to być także obecność psychoduchowa. Obecność to rzeczywiste reagowanie na potrzeby, empatia, wyrozumiałość itd. Ważne jest też otwieranie się na autentyczne uczucia wychowanka. Ta obecność powinna być dostosowana do wieku i potrzeb tych, którzy są wychowywani, do rodzaju więzi, które wychowawca tworzy z nimi. Trzeba pamiętać, że wychowuje się dzięki obecności i w obecności. Ta obecność ma być znacząca, wspierająca, wskazująca, a także dająca poczucie bezpieczeństwa.

We współczesnej cywilizacji zniewolonej zawrotnym tempem życia i konsumpcją szczególnie obecność rodziców jest konieczna. Niestety, coraz więcej ojców czy matek, nawet gdy są w domu, stają się niewidzialni, nieobecni, niezaangażowani w życie swoich dzieci. A przecież mówiąc o więzi rodzicielskiej nie można zapominać także i o tym, że w wychowaniu konieczna jest obecność rodziców i bezwarunkowa akceptacja dzieci. Stwarza ona dzieciom przestrzeń życia.

Szczególnie ważna jest obecność i opieka matki. Ma ona wielkie znaczenie zwłaszcza dla młodszych dzieci. Nie można też zapominać o ojcu, którego czynna i pozytywna obecność pomaga w kształtowaniu osobowości dziecka ${ }^{21}$. Jakość tej obecności staje się fundamentem więzi, jej głębokości, intensywności oraz trwałości. Często wychowanie odbywa się poprzez cichą, nienarzucającą się, ale znaczącą obecność wychowawcy. Niestety, wbrew pozorom, nie jest to częsta praktyka.

\section{Paradygmat destereotypizacyjny}

Edukacja uwikłana $\mathrm{w}$ globalny świat jest przepełniona stereotypami. Najczęściej stereotyp określa się jako „konstrukcję myślową, zazwyczaj powszechną wśród członków danej grupy społecznej,

20 I. Przybył, Obecność wychowania w doświadczeniu ponowoczesnej jednostki, „Nauki o Wychowaniu. Studia Interdyscyplinarne” 2016, nr 1, s. 161.

21 J. Mastalski, Jak dobrze wychowaí dziecko, dz. cyt., s. 9. 
opartą na schematycznym i uproszczonym postrzeganiu rzeczywistości [...], zabarwionym wartościująco, często bazującym na uprzedzeniach i niepełnej wiedzy"22. Stereotypów funkcjonujących w edukacji jest bardzo wiele i nie są one traktowane jako przejaw moralnej słabości osoby stereotypizującej lub jako oznaka tłumionej nieświadomej wrogości. Jest to raczej skutek naturalnej skłonności człowieka do kategoryzacji i klasyfikowania ${ }^{23}$. W rzeczywistości szkolnej tych stereotypów jest tak wiele, że mają one ogromny wpływ na postępowanie nauczycieli. Do najczęściej spotykanych można zaliczyć: stereotyp nauczyciela przegranego, stereotyp braku autorytetu, stereotyp niechcianej szkoły, stereotyp wojującego rodzica oraz stereotyp złego ucznia ${ }^{24}$. Pod wpływem stereotypizacji zachowań nauczyciel staje się tylko rzemieślnikiem tworzącym własne zasady postępowania wychowawczego. Traci szansę zostania mistrzem, dla którego tak ważne jest spotkanie oparte na zasadach dialogu ${ }^{25}$.

Stereotypy są jednak ciągle w modzie. Co więcej, wielu nauczycieli, rodziców, ale i wychowanków kieruje się nimi w swoich wyborach. Stereotypowe wychowanie niesie ze sobą poważne konsekwencje. Przed wielu laty Ivan Illich pisał, że „przejęliśmy bezwiednie pewną koncepcję dzieci. Zdecydowaliśmy, że powinny chodzić do szkoły, słuchać poleceń i nie mieć ani własnych dochodów, ani własnego życia rodzinnego. Oczekujemy po nich, że będą znały swoje obowiązki i zachowywały się jak dzieci”26.

Wychowanie według pewnych stereotypowych wzorców stwarza duże zagrożenie, bowiem w procesie wychowawczym istotna jest indywidualizacja. Wydaje się zatem, że wszelkie stereotypy dotyczące wychowania mogą zabijać indywidualność wychowanka. Każdy stereotyp w wychowaniu pociąga za sobą ambiwalentne skutki. $Z$ jednej strony wybrana taktyka wychowawcza w imię danego stereotypu ma szansę bycia skuteczną. $Z$ drugiej strony może jednak dojść do toksycznych oddziaływań będących wynikiem nietrafionych zabiegów

22 K. Olechnicki, P. Załęcki, Stownik socjologiczny, Toruń 2004, s. 204.

23 T.D. Nelson, Psychologia uprzedzeń, tłum. A. Nowak, Gdańsk 2003, s. 52.

24 J. Mastalski, Etos nauczyciela XXI wieku a stereotypy edukacyjne, w: Ewaluacja $i$ innowacje w edukacji nauczycieli, red. J. Grzesiak, t. 1, Kalisz 2007, s. 131-143.

25 Tamże, s. 137.

26 I. Illich, Spoteczeństwo bez szkoty, tłum. F. Ciemna, Warszawa 1976, s. 65-66. 
wychowawczych. Można zatem powiedzieć, że wychowanie według stereotypów jest ryzykownym zachowaniem wychowawczym. Rodzice i wychowawcy powinni o tym pamiętać.

\section{Paradygmat ekologiczny}

Podstawową komórką „ekologii ludzkiej” jest rodzina, w której człowiek otrzymuje pierwsze i decydujące wyobrażenia związane z prawdą i dobrem, uczy się, co znaczy kochać i być kochanym, a więc co konkretnie znaczy być osobą 27 . Od pewnego czasu bardzo powszechnym narzędziem pomiaru wartości środowiskowych jest Nowy Paradygmat Środowiskowy (New Environment Paradigm NEP), który opiera się na konkretnym rozumieniu relacji pomiędzy człowiekiem a światem natury. Według tego paradygmatu człowieka postrzega się jako jednostkę niewyalienowaną, stanowiącą integralną część tej natury ${ }^{28}$. Stąd też symbioza rodziny ze środowiskiem jest niejako postulatem tzw. ekologii głębokiej, w której główną tezą jest krytyka nowoczesnej techniki zaburzającej ład środowiskowy.

Mówiąc o symbiotycznej ekorodzinie, nie można także zapominać o syntonii, a więc postawie umiejętności współżycia $\mathrm{z}$ otoczeniem. Jest to łatwość w nawiązywaniu kontaktów, a także ich podtrzymywanie. Ekorodzina to grupa ludzi, którzy w szczególny sposób dbają o syntonię w domu rodzinnym. Unikają więc kłótni, nieporozumień, tworząc klimat wzajemnego zaufania, zrozumienia, a przede wszystkim dzielenia się sobą swoim człowieczeństwem ${ }^{29}$.

Niestety, współczesna cywilizacja, a w niej i edukacja, naznaczone są swoistym paradoksem ekologicznym, w którym nastawienie na proekologiczne postawy miesza się z toksycznym stylem życia. Oto kilka wymiarów owego paradoksu widocznego w codziennych wyborach nauczyciela, który nie potrafi być systematyczny w trosce

27 A. Skreczko, Wychowanie ekologiczne w rodzinie, „W Służbie Miłosierdzia” 2006, nr 8, s. 14-15.

28 R.E. Dunlap, K.D. Van Liere, A.G. Mertig, R.E. Emmet Jones, New Trends in Measuring Environmental Attitudes: Measuring Endorsement of the New Ecological Paradigm: A Revised NEP Scale, ,Journal of Social Issues” 2000, t. 56, nr 3, s. 425-442.

29 J. Mastalski, Model rodziny zastępczej - wyzwania wspótczesnej cywilizacji, „Zeszyty Naukowe Wyższej Szkoły Humanitas w Sosnowcu. Pedagogika” 2008, nr 3, s. 145-146. 
o zdrowie swoje i innych. Nie ma też wątpliwości, że przejawem omawianego paradoksu jest głęboka świadomość, a wręcz przymus instytucjonalny do stałej troski o zdrowie przy jednoczesnym zaniedbywaniu okresowych badań. Brak czasu lub zdrowe samopoczucie są najczęstszymi wymówkami w tym względzie ${ }^{30}$.

Paradygmat ekologiczny przypomina wychowawcy i wychowankowi, że zgodne współżycie ze środowiskiem naturalnym jest przejawem postawy prozdrowotnej, w której integralny rozwój ma znaczenie priorytetowe.

\section{Paradygmat spirytualny}

XXI wiek staje się stopniowo erą psychobójstwa, ale i duchobójstwa polegającego na systematycznej degradacji wszystkiego, co $\mathrm{w}$ człowieku transcendentne. $\mathrm{W}$ konsekwencji pojawia się problem z określeniem sensu życia i z odpowiedzią na podstawowe pytania dotyczące ludzkiej egzystencji. Marginalizacja duchowości przy jednoczesnym osłabieniu psychiki niosą ze sobą nieokreśloną perspektywę oraz brak pomysłu na przyszłość.

Duchobójstwo, które dotyka coraz więcej osób, ma wiele twarzy. Są nimi: brak refleksyjności, nastawienie do życia tylko chwilą obecną, zniechęcenie, powiększająca się obojętność religijna, tendencje samobójcze, naskórkowa religijność, a także zaniedbania w sferze ducha. Miał rację przed laty Romano Guardini, gdy pisał:

Problem religijny naszego czasu nie polega przede wszystkim na pytaniu, czy Bóg jest i jaki jest, ale dotyczy bardziej problemu, czy i jak jest możliwe wspófistnienie świata i Boga? Czy w takim wspófistnieniu może istnieć Bóg, a człowiek - zwieńczenie dzieła stworzenia - może pozostać człowiekiem?31.

Okazuje się, że „dynamika przemian kulturowych i społecznych naszych ponowoczesnych czasów powoduje pluralizację systemów wartości wyznaczoną przez wielość często sprzecznych ze sobą propozycji aksjologicznych, charakteryzujących wiele rozwiniętych, jak

30 J. Mastalski, Szkota wobec wyzwań globalizmu, „Wychowanie na co Dzień” 2007, nr 7-8, s. 3-4.

31 R. Guardini, Diario. Appunti e testi dal 1942 al 1964, Brescia 1964, s. 109. 
i rozwijających się społeczeństw"32. Stąd też trzeba przypominać paradygmat spirytualny, który kieruje człowieka w stronę duchowości, dotykając jego najgłębszej struktury. Duchowość w procesie wychowania ma przecież ogromne znaczenie dla integralnego rozwoju. Pomijanie lub marginalizowanie jej prowadzi do pustki i psychologizacji procesu edukacji.

Papież Franciszek w swojej encyklice Lumen fidei napisal:

Światło wiary jest w stanie uwydatnić bogactwo ludzkich relacji, to, że mogą trwać, być wiarygodne, ubogacać wspólne życie. Wiara nie oddala od świata i nie jest czymś oderwanym od konkretnego zaangażowania współczesnych ludzi. Bez wiarygodnej miłości nie byłoby niczego, co sprawia, że ludzie prawdziwie są zjednoczeni. Jedność między nimi byłaby do pomyślenia jedynie jako oparta na użyteczności, wspólnych interesach, lęku, ale nie na dobru wspólnego życia czy na radości, jaką może budzić po prostu obecność drugiego człowieka. Wiara pozwala zrozumieć architekturę relacji ludzkich, ponieważ dostrzega ich głęboki fundament i ostateczne przeznaczenie w Bogu, i w Jego miłości, dzięki temu oświeca sztukę budowania, służąc dobru wspólnemu ${ }^{33}$.

Należy zatem docenić duchowy rozwój człowieka, a w nim religijne odniesienia do sacrum.$$
* * *
$$

Jak widać, istnieje wiele edukacyjnych paradygmatów dotyczących formacji, które we współczesnym świecie są albo zaniedbane, albo zmarginalizowane. Jest zatem ogromna potrzeba przypominania o nich oraz ukazywania ich ważności i potrzeby. Formacja młodego pokolenia jest bowiem „inwestycją” na przyszłość, ale odpowiedzialność za nią spoczywa na całym społeczeństwie już dzisiaj. Stąd też dobrą pointą tych rozważań będą słowa Andrzeja de Tchorzewskiego:

Rodzic i nauczyciel muszą pamiętać, że współczesny świat, w który wrasta młody człowiek, cechuje niespotykany chaos aksjonormatywny. Jego źródeł należy upatrywać $\mathrm{w}$ następujących zjawiskach: różnorodnych kryzysach, procesach transformacyjnych, czyli nierewolucyjnych zmianach, przeobrażeniach i przekształceniach we wszystkich bądź niektórych dziedzinach i obszarach życia różnych wspólnot, grup społecznych, narodów i państw, i integracyjnych, czyli charakterystycznych proce-

32 L. Korporowicz, Osobowośc i komunikacja w spoteczeństwie transformacji, Warszawa 1995, s. 25.

33 Papież Franciszek, Encyklika „Lumen fidei”, Kraków 2013, nr 51.
} 
sach, a niekiedy tylko trendach. [...] Droga do sukcesu pedagogicznego wymaga zatem pokonywania i przezwyciężania wielu trudnych do przewidzenia przeszkód przez wszystkich, którzy są w pełni świadomi znaczenia wychowania dorastających. Na tej drodze mają jednak miejsce chwilowe, a niekiedy i długotrwałe załamania, poczucie zawodu, a nawet przegranej w realizacji stawianych celów wychowawczych ${ }^{34}$.

Przypomniane paradygmaty mogą w sposób znaczący pomóc w osiąganiu owych celów.

\section{Bibliografia}

Bauman Z., Ptynny lęk, tłum. J. Margański, Wydawnictwo Literackie, Kraków 2008.

Bobrowski I., Zaproszenie do językoznawstwa, PAN, Kraków 1998.

Chlewiński Z., Formacja, w: Encyklopedia katolicka, t. 5, red. L. Bieńkowski i in., Towarzystwo Naukowe KUL, Lublin 1989, kol. 389.

Denek K., W stronepedagogiki czasu, w: Opieka. Wychowanie. Ksztatcenie. Moduty edukacyjne, red. W. Woronowicz, D. Apanel, Oficyna Wydawnicza „Impuls”, Kraków 2010, s. 9-44.

Dunlap R.E., Van Liere K.D., Mertig A.G., Emmet Jones R.E., New Trends in Measuring Environmental Attitudes: Measuring Endorsement of the New Ecological Paradigm: A Revised NEP Scale, „Journal of Social Issues” 2000, t. 56, nr 3, s. 425-442.

Fromm E., O sztuce mitości, tłum. A. Bogdański, Sagittarius, Warszawa 1994.

Guardini R., Diario. Appunti e testi dal 1942 al 1964, Editore Morcelliana, Brescia 1964.

Hłobił A., Indywidualizacja ksztatcenia szansq urzeczywistnienia potrzeb i możliwości uczniów, „Edukacja Humanistyczna” 2015, nr 1(32), s. 113-121.

Illich I., Spoteczeństwo bez szkoty, tłum. F. Ciemna, PIW, Warszawa 1976.

Jan Paweł II, Adhortacja Apostolska „Christifideles laici”, Wydawnictwo św. Stanisława BM, Kraków 1988.

Jan Paweł II, List do Rodzin, Wydawnictwo św. Stanisława BM, Kraków 1998.

Jan Paweł II, Przemówienie do katechetów nauczycieli i uczniów (Wtoctawek, 6.06.1991), „L'Osservatore Romano” 1991, nr 6, s. 5-6.

Korporowicz L., Osobowość $i$ komunikacja w społeczeństwie transformacji, Instytut Kultury - Instytut Socjologii UW, Warszawa 1995.

Kuszak K., Dynamika rozwoju samodzielności dziecka w wieku przedszkolnym, Wydawnictwo Naukowe UAM, Poznań 2006.

Mastalski J., Model rodziny zastepczej - wyzwania wspótczesnej cywilizacji, „Zeszyty Naukowe Wyższej Szkoły Humanitas w Sosnowcu. Pedagogika” 2008, nr 3, s. 145-157.

34 A. de Tchorzewski, Sukces i porażka w wychowaniu, „Edukacja Elementarna w Teorii i Praktyce" 2014, nr 4(34), s. 14-15. 
Mastalski J., Etos nauczyciela XXI wieku a stereotypy edukacyjne, w: Ewaluacja i innowacje w edukacji nauczycieli, red. J. Grzesiak, t. 1, Wydział Pedagogiczno-Artystyczny UAM w Kaliszu, Kalisz 2007, s. 131-147.

Mastalski J., Jak dobrze wychować dziecko, Salwator, Kraków 2014.

Mastalski J., Przestrzenie obaw i dylematów zwiqzanych z jakościq ksztatcenia, w: Jakość innowacji i ewaluacja w edukacji, red. J. Grzesiak, Wydział Pedagogiczno-Artystyczny UAM w Kaliszu - PWSZ w Koninie, Kalisz - Konin 2015, s. 39-50.

Mastalski J., Szkota wobec wyzwań globalizmu, „Wychowanie na co Dzień” 2007, nr 7-8, s. 3-4.

Mastalski J., Zasady edukacyjne w katechezie. Na podstawie badań przeprowadzonych w krakowskich gimnazjach, Wydawnictwo Naukowe PAT, Kraków 2002.

Nelson T.D., Psychologia uprzedzeń, tłum. A. Nowak, Gdańskie Wydawnictwo Psychologiczne, Gdańsk 2003.

Olechnicki K., Załęcki P., Stownik socjologiczny, Wydawnictwo Graffiti, Toruń 2004.

Papież Franciszek, Encyklika „Lumen fidei”, Wydawnictwo św. Stanisława BM, Kraków 2013.

Przybył I., Obecnośc wychowania w doświadczeniu ponowoczesnej jednostki, „Nauki o Wychowaniu. Studia Interdyscyplinarne” 2016, nr 1, s. 156-171.

Rowid H., Podstawy $i$ zasady wychowania, Wydawnictwo Oświatowe „Wspólna Sprawa”, Warszawa 1957.

Skreczko A., Wychowanie ekologiczne w rodzinie, „W Służbie Miłosierdzia” 2006, t, 3, nr 8, s. 4.

Skreczko A., Wychowanie do odpowiedzialności, „W Służbie Miłosierdzia” 2007, t. 4, nr 11, s. 4.

Szałach S., Zaufanie w relacjach interpersonalnych - wybrane aspekty, „Edukacja Humanistyczna” 2013, nr 1(28), s. 177-183.

Sztompka P., Zaufanie. Fundament spoteczeństwa, Znak, Kraków 2007.

Tchorzewski A. de, Sukces i porażka w wychowaniu, „Edukacja Elementarna w Teorii i Praktyce” 2014, nr 4(34), s. 9-26.

Zeichner K.M., Alternative Paradigms of Teacher Education, "Journal of Teacher Education” 1983, t. 34, nr 3, s. 3-9.

\section{ADRES DO KORESPONDENCJ:}

Ks. prof. dr hab. Janusz Mastalski

Uniwersytet Papieski Jana Pawła II w Krakowie

Wydział Nauk Społecznych

Katedra Pedagogiki Ogólnej

jmas@neo.pl 